\title{
UNLV Special Collections in the Twenty-First Century
}

University of Nevada Las Vegas (UNLV) Special Collections is consistently striving to provide several avenues of discovery to its diverse range of patrons. Specifically, UNLV Special Collections has planned and implemented several online tools to facilitate unearthing treasures in the collections. These online tools incorporate Web 2.0 features as well as searchable interfaces to collections.

$\mathrm{T}$ he University of Nevada Las Vegas (UNLV) Special Collections has been working toward creating a visible archival space in the twenty-first century that assists its patrons' quest for historical discovery in UNLV's unique Southern Nevada, gaming, and Las Vegas collections. This effort has helped patrons ranging from researchers to students to residents. Special Collections has created a discovery environment that incorporates several points of access, including virtual exhibits, a collection-wide search box, and digital collections. UNLV Special Collections also has added Web 2.0 features to aid in the discovery and enrichment of this historical information. These new features range from a What's New blog to a digital collection with interactive features.

The first point of discovery within the UNLV Special Collections website began with the virtual exhibits. Staff created the virtual exhibits as static HTML pages that showcased unique materials housed within UNLV Special Collections. They showed the scope and diversity of materials on a specific topic available to researchers, faculty, and students.

One virtual exhibit is "Dino at the Sands" (figure 1), a point of discovery for the history not only of Dean Martin but of many Rat Pack exploits. ${ }^{1}$ The photographs in this exhibit come from the Sands Collection. It is a static HTML page, and it provides information and pictures regarding one of Las Vegas' most famous entertainers. This exhibit contains links to Rat Pack information and various resources on Dean Martin, including photographs, books, and videotapes.

A second mode of discovery within the UNLV Special Collections website is its new "Search Special Collections" Google-like search box (figure 2). This is located on the homepage and searches the manuscript, photograph, and oral history primary source collections. ${ }^{2}$ The purpose is to aid in the discovery of material within the collections that is not yet detailed in the public online catalog. In the past researchers would have to work through the Special Collection's website to locate the resources. They can now

Thomas Sommer (thomas.sommer@unlv.edu) is University and Technical Services Archivist in Special Collections at the University of Nevada Las Vegas Libraries.

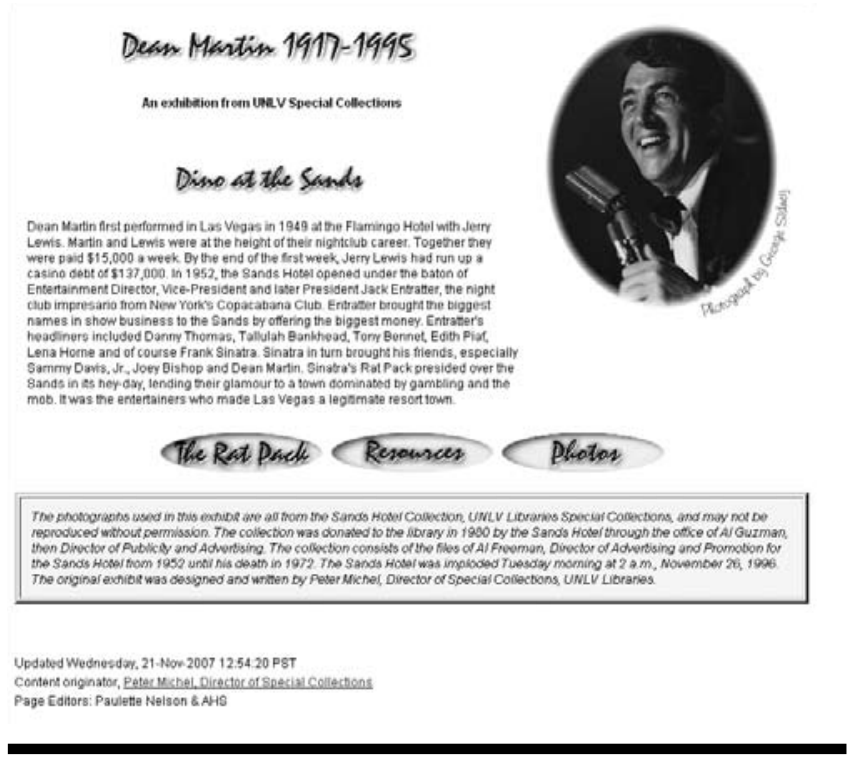

Figure 1. "Dino at the Sands" exhibit

\section{Welcome to UNLV Special Collections}
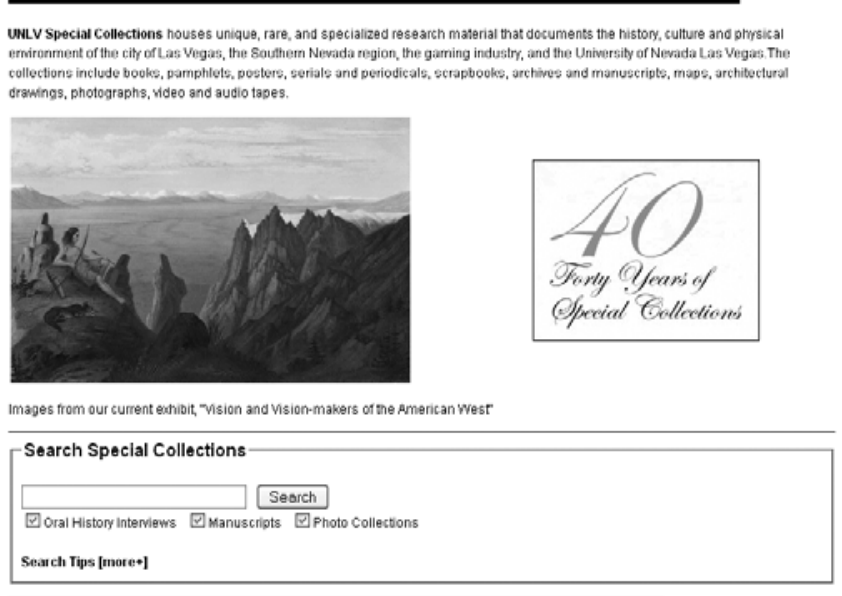

Visit our Digital Collections \& Exhibits...

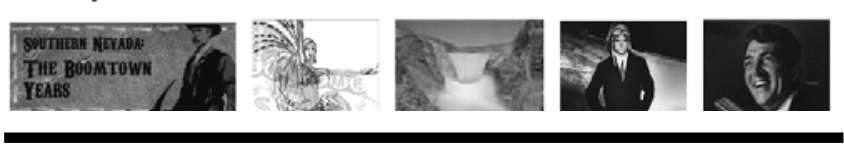

Figure 2. UNLV Special Collections search box

go to one place to search for various types of material-a one-stop shop. The search results are easy to read and highlight the search term (see figure 3$)^{3}{ }^{3}$

The third point of access is the digital collection. These collections are digital copies of original materials located within the archives. The digital copies are presented online, described, and organized for easy access. Each collection offers full-text searches, browsing, zoom, pan, 


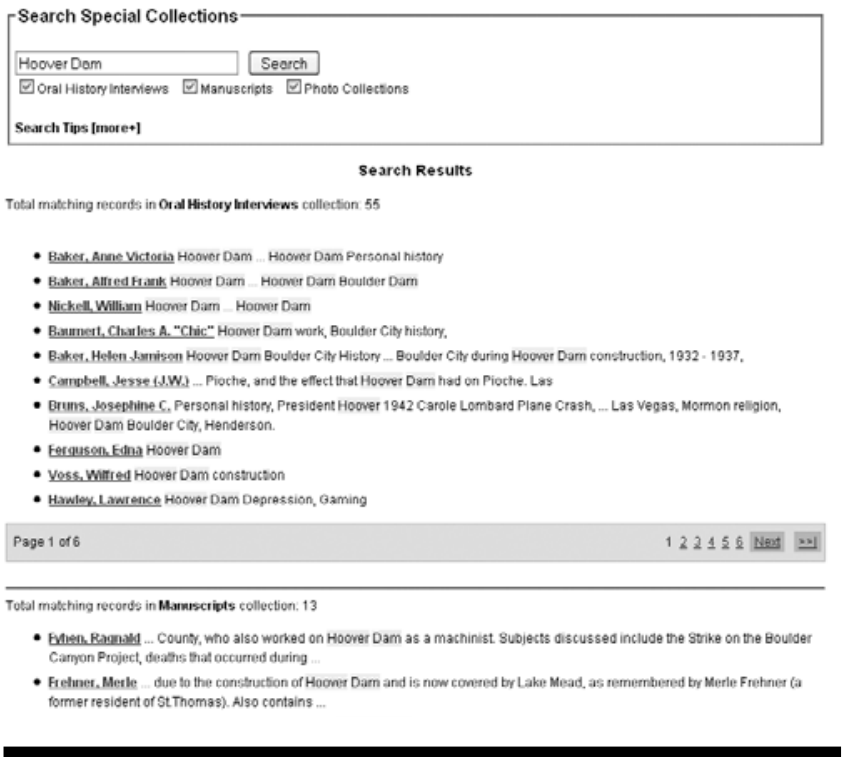

Figure 3. Hoover Dam search results

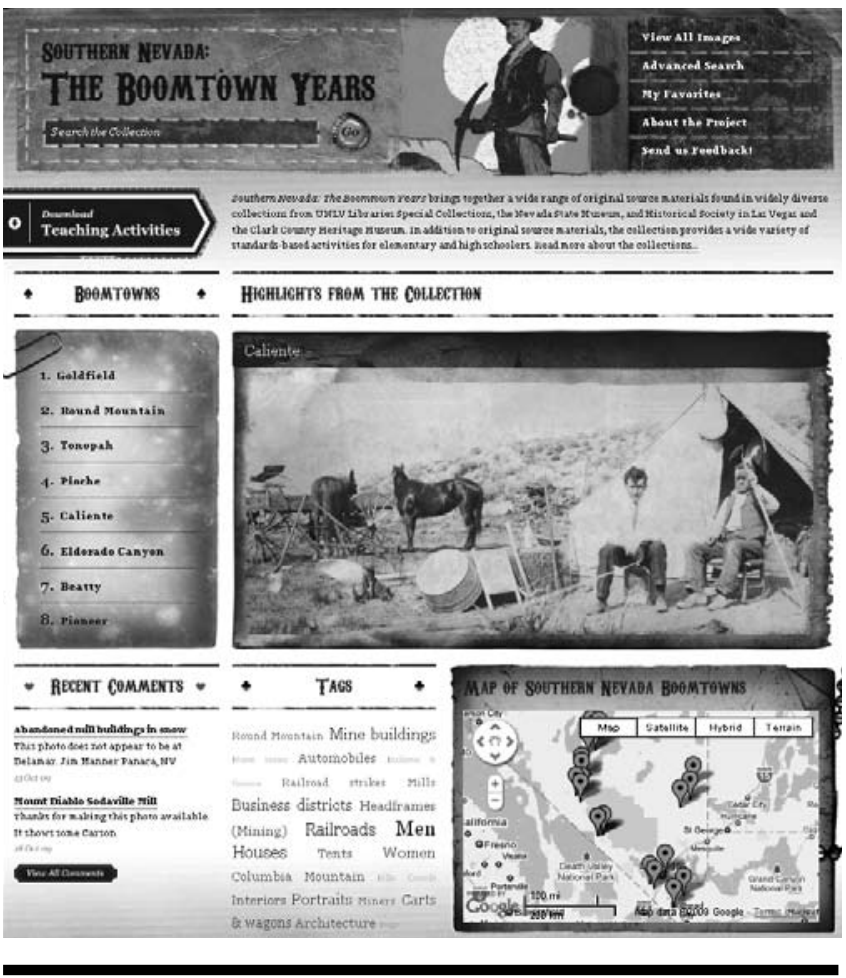

Figure 4. "Southern Nevada: The Boomtown Years" digital collection

side-by-side comparison, and exporting for presentation and reuse.

The newest example of a digital collection is "Southern Nevada: The Boomtown Years" (figure 4). ${ }^{4}$ This collection
What's New in Special Collections News and Announcements from UNLV Special Collections

\author{
Asian-Pacific Entertainers in Las Vegas Exhibit \\ By su Kim Chung on May 8, 2009 5:10 PM I Permalink \\ In celebration of Asian-Pacific Heritage Month, Special Collections has created an \\ exhibit featuring historical photographs and documents on Asian-Pacific entertainers in \\ Las Vegas over the years. Materials on display on the 3rd Floor of Lied Library include \\ items such as this orignal program from the China Doll Revue which appeared at the \\ Thunderbird Hotel and Casino in 1959. Please stop by and take a look!
}

\section{New Digital Project: Southern Nevada: The Boomtown Years, 1900-1925}

By su Kim Chung on May 8, 2009 5:09 PWI Permalink

Our latest digital project - Southern Nevada: The Boomtown Years, 1900-1920-1925 -- is now live. Access this fabulous collection of digitzed photographs, correspondence, maps, ledgers, and more -- along with a teacher's guide providing activities for grades 3-12 in eleven subject areas -- at: http://digital.library.unlv. edu/boomtown

Figure 5. "What's New" blog

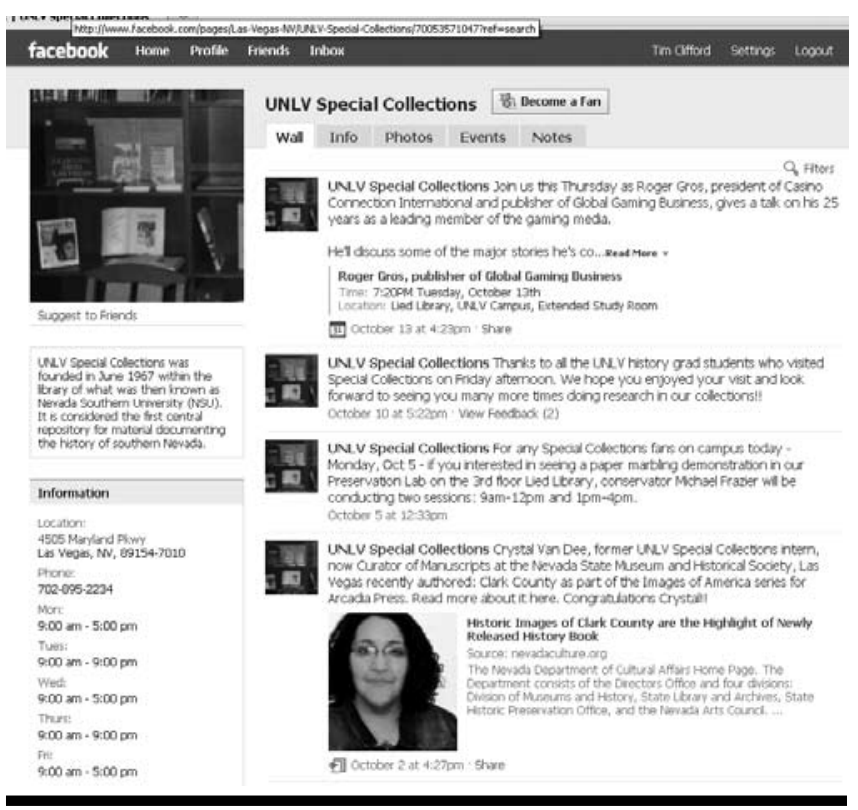

Figure 6. UNLV Special Collection Facebook page

brings together a wide range of original materials from various collections located within UNLV Special Collections, the Nevada State Museum, the Historical Society in Las Vegas, and the Clark County Heritage Museum. It even provides standards-based activities for elementary and high school students.

This project was funded by the Nevada State Library and Archives under the Library Services and Technology Act (LSTA) as amended through the Institute of Museum 


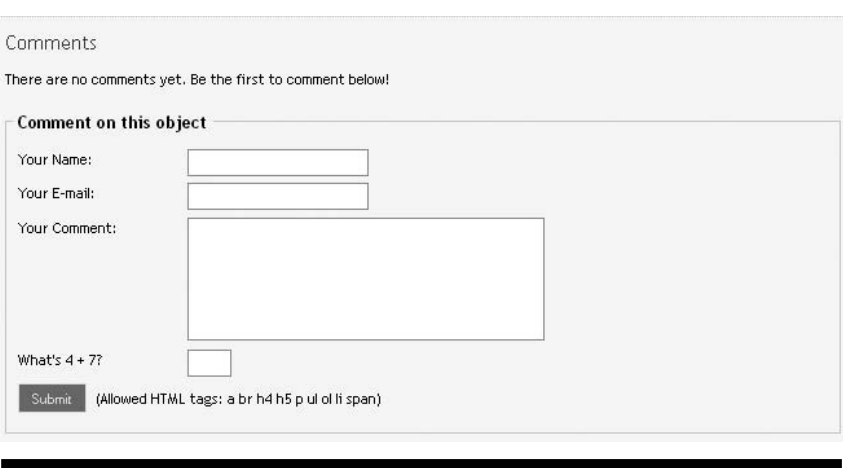

Figure 7. Comments section for Aerial View of Hughes Aircraft Plant photograph

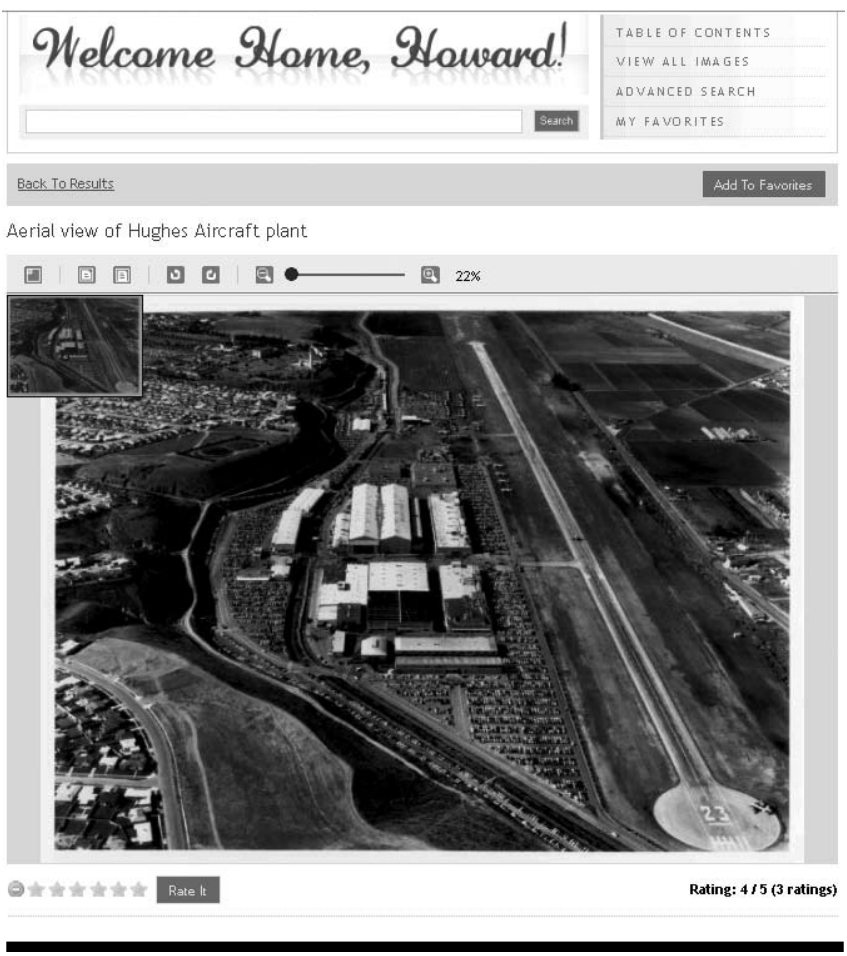

Figure 8. "Rate It" feature for Aerial View of Hughes Aircraft Plant photograph

and Library Services (IMLS). UNLV Special Collections Director Peter Michel selected the content. The team included fourteen members, four of whom were funded by the grant. Christy Keeler, PhD, created the educator pages and designed the student activities.

New collections are great, but users have to know they exist. To announce new collections and displays, Special Collections first added a What's New blog that includes an RSS feed to keep patrons up-to-date on new messages (figure 5)..$^{5}$ Another avenue of interaction was

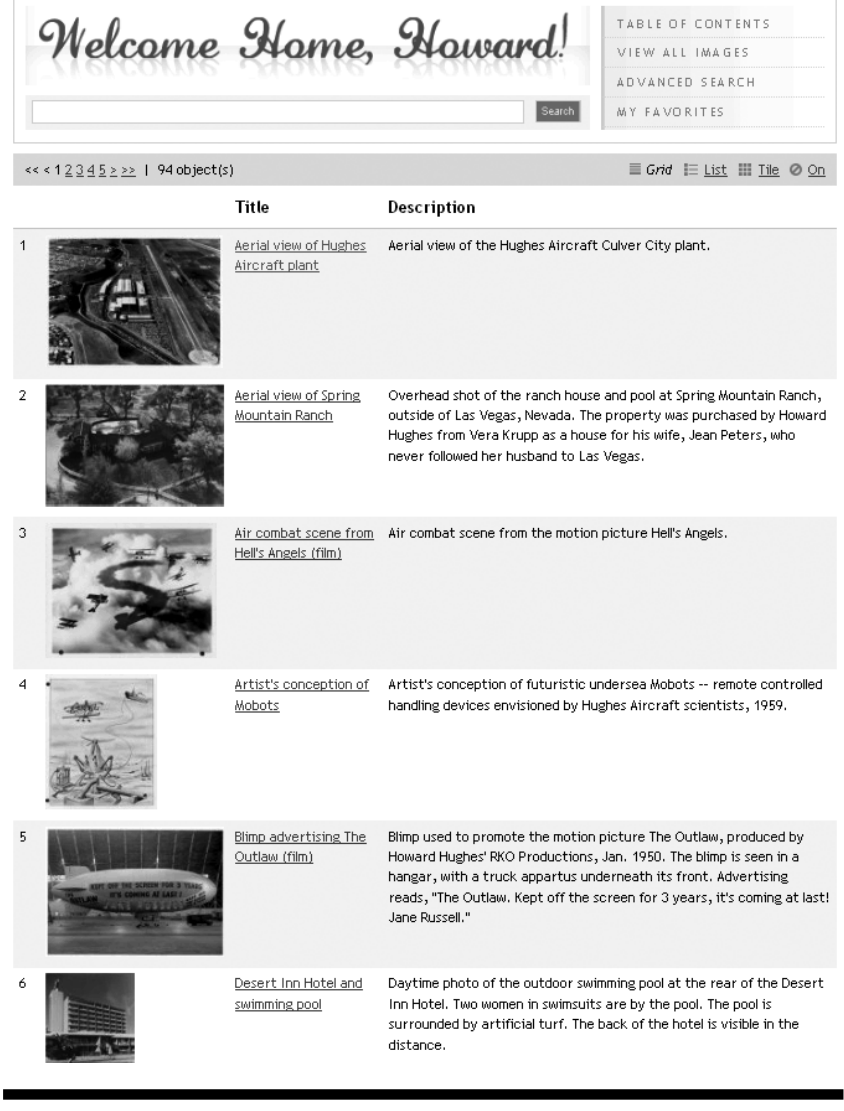

Figure 9. RSS feature for the index to the "Welcome Home Howard" digital collection

implemented in April 2009 when Special Collections created its own Facebook page (figure 6). ${ }^{6}$ Students and researchers are encouraged to become fans. Status updates with images and links to southern Nevada and Las Vegas resources lead the fans back to the main website where the other treasures can be discovered.

Special Collections has implemented various Web 2.0 features within its newest digital collections. Specifically, it added a comments section, a "Rate It" feature, and an RSS feature to its latest digital collections (figures 7, 8, and 9). These latest trends enrich the collections' resources with patron-supplied information. ${ }^{7}$

As is apparent, UNLV Special Collections implemented several online tools to allow patrons to discover its extensive primary resources. These tools range from virtual exhibits and digital collections with Web 2.0 features to blogs and social networking sites. Special Collections has endeavored to stay on top of the latest trends to benefit its patrons and facilitate their discovery of historical materials in the twenty-first century.

Continued on page 190 


\section{Reference}

UNLV Special Collections continued from page 186

\section{References}

1. Peter Michel, "Dino at the Sands," UNLV Special Collections, http://www.library.unlv.edu/speccol/dino/index.html (accessed July 28, 2009).

2. PeterMichel, "UNLVSpecialCollectionsSearchBox."UNLV Special Collections. http://www.library.unlv.edu/speccol/ index.html (accessed July 28, 2009).

3. UNLV Special Collections search results, "Hoover Dam," http://www.library.unlv.edu/speccol/databases/index .php?search_query=hoover+dam\&btS=Search\&cols[]=oh\&cols []= man\&cols[] = photocoll\&act $=2$ (accessed October 27, 2009).

4. UNLV Libraries, "Southern Nevada: The Boomtown Years," http://digital.library.unlv.edu/boomtown/ (accessed July 28, 2009).
5. UNLV Special Collections, "What's New in Special Collections," http://blogs.library.unlv.edu/whats_new_in_special_ collections / (accessed July 28, 2009).

6. UNLV Special Collections, "UNLV Special Collections Facebook Homepage," http://www.facebook.com/home .php?\#/pages/Las-Vegas-NV/UNLV-Special-Collections/70053 571047? ref=search (accessed July 28, 2009).

7. UNLV Libraries, "Comments Section for the Aerial View of Hughes Aircraft Plant Photograph," http://digital.library .unlv.edu/hughes/dm.php/hughes/82 (accessed July 28, 2009); UNLV Libraries, "'Rate It' feature for the Aerial View of Hughes Aircraft Plant Photograph," http://digital.library.unlv.edu/ hughes/dm.php/hughes/82 (accessed July 28, 2009); UNLV Libraries, "RSS feature for the index to the Welcome Home Howard Digital Collection" http:/ /digital.library.unlv.edu/hughes/ dm.php/ (accessed July 28, 2009).

\section{STATEMENT OF OWNERSHIP, MANAGEMENT, AND CIRCULATION}

Information Technology and Libraries, Publication No. 280-800, is published quarterly in March, June, September, and December by the Library Information and Technology Association, American Library Association, 50 E. Huron St., Chicago, Illinois 60611-2795. Editor: Marc Truitt, Associate Director, Information Technology Resources and Services, University of Alberta, K Adams/Cameron Library and Services, University of Alberta, Edmonton, AB T6G 2J8 Canada. Annual subscription price, \$65. Printed in U.S.A. with periodical-class postage paid at Chicago, Illinois, and other locations. As a nonprofit organization authorized to mail at special rates (DMM Section 424.12 only), the purpose, function, and nonprofit status for federal income tax purposes have not changed during the preceding twelve months.

\section{EXTENT AND NATURE OF CIRCULATION}

(Average figures denote the average number of copies printed each issue during the preceding twelve months; actual figures denote actual number of copies of single issue published nearest to filing date: September 2009 issue). Total number of copies printed: average, 5,096; actual, 4,751. Mailed outside country paid subscriptions: average, 4,090; actual, 3,778. Sales through dealers and carriers, street vendors, and counter sales: average, 430; actual 399. Total paid distribution: average, 4,520; actual, 4,177. Free or nominal rate copies mailed at other classes through the USPS: average, 54; actual, 57. Free distribution outside the mail (total): average, 127; actual, 123. Total free or nominal rate distribution: average, 181; actual, 180. Total distribution: average, 4,701; actual, 4,357. Office use, leftover, unaccounted, spoiled after printing: average, 395; actual, 394. Total: average, 5,096; actual, 4,751. Percentage paid: average, 96.15; actual, 95.87.

Statement of Ownership, Management, and Circulation (PS Form 3526, September 2007) filed with the United States Post Office Postmaster in Chicago, October 1, 2009. 